\title{
Spatial distribution of microzooplankton in different areas of the northern Antarctic Peninsula region, with an emphasis on tintinnids
}

\author{
Marina Monti-Birkenmeier ${ }^{1}\left[\right.$ - Tommaso Diociaiuti ${ }^{1} \cdot$ Thomas H. Badewien $^{2} \cdot$ Anne-Christin Schulz $^{2}$. \\ Anna Friedrichs ${ }^{2} \cdot$ Bettina Meyer ${ }^{3,4,5}$
}

Received: 29 December 2020 / Revised: 17 June 2021 / Accepted: 22 June 2021 / Published online: 12 July 2021

(c) The Author(s) 2021

\begin{abstract}
The Western Antarctic Peninsula (WAP) is experiencing rapid climate warming, resulting in affecting the marine food web. To investigate the microzooplankton spatial distribution and to assess how climate change could affect the tintinnids community, sea water samples were collected during late summer 2018 at 19 stations in three different areas: Deception Island, Elephant Island and Antarctic Sound. The microzooplankton community comprised mainly tintinnids, aloricate ciliates, heterotrophic dinoflagellates and micrometazoans. Microzooplankton abundance varied between 3 and 109 ind. $\mathrm{L}^{-1}$ and biomass ranged from 0.009 to $2.55 \mu \mathrm{g} \mathrm{C} \mathrm{L}^{-1}$. Significant differences in terms of abundance and taxonomic composition of microzooplankton were found among the three sampling areas. Deception Island area showed $44 \%$ of tintinnids and the rest were heterotrophic dinoflagellate, aloricate ciliates and micrometazoans. In Elephant Island and Antarctic Sound areas, tintinnids reached, respectively, $73 \%$ and $83 \%$ of the microzooplankton composition, with all the other groups varying between 20 and 30\%. Tintinnids were the most representative group in the area, with the species Codonellopsis balechi, Codonellopsis glacialis, Cymatocylis convallaria and Cymatocylis drygalskii. The highest amounts of tintinnids were found at the surface and $100 \mathrm{~m}$ depth. The above mentioned species may be considered key species for the WAP and therefore they can be used to track environmental and hydrographical changes in the area. In late summer, microzooplankton presented low abundances and biomass, nevertheless they represented an important fraction of the planktonic community in the area.
\end{abstract}

Keywords Protists $\cdot$ Ciliates $\cdot$ Tintinnids $\cdot$ Heterotrophic dinoflagellates $\cdot$ Biomass

Marina Monti-Birkenmeier

mmonti@inogs.it

1 National Institute of Oceanography and Applied Geophysics (OGS), Via A. Piccard 54, 34151 Trieste, Italy

2 Institute for Chemistry and Biology of the Marine Environment (ICBM), University of Oldenburg, Schleusenstrasse 1, 26382 Wilhelmshaven, Germany

3 Alfred Wegener Institute Helmholtz Centre for Polar and Marine Research, Am Handelshafen 12, Bremerhaven, Germany

4 Institute for Chemistry and Biology of the Marine Environment (ICBM), University of Oldenburg, Carl-von-Ossietzky-Strasse 9-11, 26111 Oldenburg, Germany

5 Helmholtz Institute for Functional Marine Biodiversity (HIFMB), University of Oldenburg, Ammerländer Heerstrasse 231, Oldenburg, Germany

\section{Introduction}

The Western Antarctic Peninsula (WAP) is one of the fastest warming areas on the planet, making this part of the Southern Ocean an invaluable observatory of ecosystem responses to climate change (Ducklow et al. 2012). Strong winds and the Antarctic Circumpolar Current (ACC) lead to upwelling processes and induce nutrient rich water to reach the surface at the polar front area (Dietrich et al. 1975; Talley et al. 2011; Siedler et al. 2013).

Additionally, the Antarctic Coastal Current (ACoC), acting as a counter current to the ACC, induces counterrotating current regimes including mixing processes (Moffat and Meredith 2018). Among others, characterizing water masses around WAP are Antarctic Surface Water (AASW), Antarctic Intermediate Water (AAIW) as well as Shelf water masses (Talley et al. 2011). 
The warming in the region has resulted in shorter winter sea ice, increase in surface water temperature, melting of glaciers and glacial runoff (Whitehouse et al. 2008; Turner et al. 2009). These environmental changes have been shaping the distribution of phytoplankton biomass over the WAP region. Given that phytoplankton is at the base of the Antarctic trophic food web, variations in the autotrophic component should have significant consequences for the rest of the ecosystem. The changing phytoplankton composition and chlorophyll $a$ trend (Montes-Hugo et al. 2009) in the northern WAP promotes the decline in diatoms abundances and the contextual increase in abundance of smaller organisms, resulting in the dominance of nanophytoplankton (Mendes et al. 2013; Sangrà et al. 2014; Garcia et al. 2019). This last evidence can affect the distribution and community composition of microzooplankton, as well as higher trophic levels.

Microzooplankton (MZP) include organisms with dimensions between 20 and $200 \mu \mathrm{m}$ in size and, in the Antarctic sea, they comprise mainly ciliates (aloricate and tintinnids), heterotrophic dinoflagellates, the first larval stage of micrometazoans and other protozoa (Foraminifera, Radiozoa, Cercozoa and Heliozoa (Monti and Fonda Umani 2000; Gowing and Garrison 2003; Monti et al. 2016). Microzooplankton can play a key role in removing small phytoplankton biomass (Burkill et al. 1995; Sherr and Sherr 2007; Garcia et al. 2016) and, at the same time, heterotrophic protists can be considered as a food sources for a large number of pelagic organisms such as krill and salps (Calbet and Saiz 2005). The recent shift to small phytoplankton cells affects the structure and dynamic of the Antarctic food structure (Beans et al. 2008; Mendes et al. 2013), with MZP becoming more and more important in the Southern Ocean ecosystem as a predator of smaller phytoplankton. On the other hand, endemic Antarctic tintinnids are characterized by an unusually large oral diameter (Dolan et al. 2012) and the incoming changes can influence the tintinnids species composition. The modification in the MZP composition and quantity might trigger a cascade of short- and long-term changes in ecosystem structure and function, affecting both biodiversity and biogeochemical cycles in the pelagic system.

Despite the MZP importance, only a few studies are available regarding their abundance and composition in the area (Boltovskoy et al. 1989; Alder and Boltovskoy 1991, 1993; Thompson et al. 1999; Calbet et al. 2005; Thompson and Alder 2005; Garzio and Steinberg 2013; Garcia et al. 2016, 2019).

The present study aimed to implement our knowledge of the distribution, abundance and biomass of the MZP community in the WAP area. The surveyed area, between the South Shetland Islands and the northern part of WAP, showed a broad range of physicochemical conditions and the period of sampling (late summer) was appropriate to study the change in the autotrophic and heterotrophic compartments. We sought to determine the spatial distribution of the MZP population sampled in the area, with particular attention to the study of tintinnid species. This study will provide new data for the area and can serve as a reference point for subsequent studies to assess how climate change will affect the MZP community structure and the food web in the WAP area.

\section{Materials and methods}

\section{Samples collection}

Sampling was carried out during the expedition ANT PS112 (18 March to 6 May 2018) with R.V. "Polarstern" in the Antarctic Peninsula region (Table 1). Sea water samples were collected at 19 stations, located in three different regions (Fig. 1) and at 3 to 5 depths: subsurface (5-20 m), DMC (depth maximum chlorophyll), $100 \mathrm{~m}, 200 \mathrm{~m}$ and $500 \mathrm{~m}$. Station 24 was sampled only at subsurface $(0-30 \mathrm{~m})$ using a $20-\mu \mathrm{m}$ mesh net for qualitative MZP analyses. The three sampling areas were: Deception Island (DI), Elephant Island (EI) and Antarctic Sound (AS).

We used a Sea-Bird Electronics Inc. CTD SBE 911plus probe, SN 09-1266, attached to a SBE 32 Carousel Water Sampler SN 32-1119 containing 24 20-L Ocean Test Equipment Inc. bottles. The CTD system was equipped with

Table 1 Sampling area, stations, dates and coordinates. DI Deception Island, EI Elephant Island, AS Antarctic Sound

\begin{tabular}{lllll}
\hline Area & Station & Date & Latitude & Longitude \\
\hline DI & PS112_17 & $26 / 03 / 2018$ & $62^{\circ} 45.599^{\prime} \mathrm{S}$ & $059^{\circ} 00.431^{\prime} \mathrm{W}$ \\
DI & PS112_20 & $26 / 03 / 2018$ & $63^{\circ} 00.008^{\prime} \mathrm{S}$ & $060^{\circ} 00.008^{\prime} \mathrm{W}$ \\
DI & PS112_24 & $27 / 03 / 2018$ & $62^{\circ} 35.006^{\prime} \mathrm{S}$ & $059^{\circ} 52.738^{\prime} \mathrm{W}$ \\
DI & PS112_25 & $01 / 04 / 2018$ & $62^{\circ} 53.016^{\prime} \mathrm{S}$ & $060^{\circ} 14.037^{\prime} \mathrm{W}$ \\
DI & PS112_34 & $04 / 04 / 2018$ & $61^{\circ} 15.333^{\prime} \mathrm{S}$ & $060^{\circ} 59.452^{\prime} \mathrm{W}$ \\
DI & PS112_41 & $05 / 04 / 2018$ & $61^{\circ} 44.962^{\prime} \mathrm{S}$ & $059^{\circ} 00.008^{\prime} \mathrm{W}$ \\
EI & PS112_55 & $08 / 04 / 2018$ & $61^{\circ} 01.345^{\prime} \mathrm{S}$ & $054^{\circ} 47.170^{\prime} \mathrm{W}$ \\
AS & PS112_81 & $14 / 04 / 2018$ & $63^{\circ} 57.798^{\prime} \mathrm{S}$ & $054^{\circ} 08.383^{\prime} \mathrm{W}$ \\
AS & PS112_87 & $15 / 04 / 2018$ & $63^{\circ} 43.383^{\prime} \mathrm{S}$ & $055^{\circ} 24.619^{\prime} \mathrm{W}$ \\
AS & PS112_90 & $16 / 04 / 2018$ & $63^{\circ} 43.712^{\prime} \mathrm{S}$ & $056^{\circ} 50.379^{\prime} \mathrm{W}$ \\
AS & PS112_98 & $17 / 04 / 2018$ & $63^{\circ} 38.776^{\prime} \mathrm{S}$ & $056^{\circ} 29.579^{\prime} \mathrm{W}$ \\
AS & PS112_101 & $18 / 04 / 2018$ & $63^{\circ} 19.779^{\prime} \mathrm{S}$ & $056^{\circ} 48.487^{\prime} \mathrm{W}$ \\
AS & PS112_103 & $19 / 04 / 2018$ & $62^{\circ} 44.931^{\prime} \mathrm{S}$ & $056^{\circ} 30.157^{\prime} \mathrm{W}$ \\
EI & PS112_106 & $20 / 04 / 2018$ & $61^{\circ} 53.935^{\prime} \mathrm{S}$ & $053^{\circ} 54.598^{\prime} \mathrm{W}$ \\
EI & PS112_118 & $25 / 04 / 2018$ & $60^{\circ} 58.578^{\prime} \mathrm{S}$ & $054^{\circ} 58.920^{\prime} \mathrm{W}$ \\
EI & PS112_119 & $26 / 04 / 2018$ & $60^{\circ} 59.998^{\prime} \mathrm{S}$ & $054^{\circ} 35.694^{\prime} \mathrm{W}$ \\
EI & PS112_120 & $27 / 04 / 2018$ & $60^{\circ} 57.675^{\prime} \mathrm{S}$ & $054^{\circ} 44.713^{\prime} \mathrm{W}$ \\
EI & PS112_121 & $28 / 04 / 2018$ & $60^{\circ} 58.103^{\prime} \mathrm{S}$ & $054^{\circ} 52.255^{\prime} \mathrm{W}$ \\
EI & PS112_122 & $29 / 04 / 2018$ & $60^{\circ} 58.965^{\prime} \mathrm{S}$ & $054^{\circ} 55.673^{\prime} \mathrm{W}$ \\
\hline
\end{tabular}


Fig. 1 Location of the stations sampled. The oval box distinguishes the three areas: Deception Island, Elephant Island and Antarctic Sound. DP Drake Passage, $B S$ Bransfield Strait, WAP Western Antarctic Peninsula

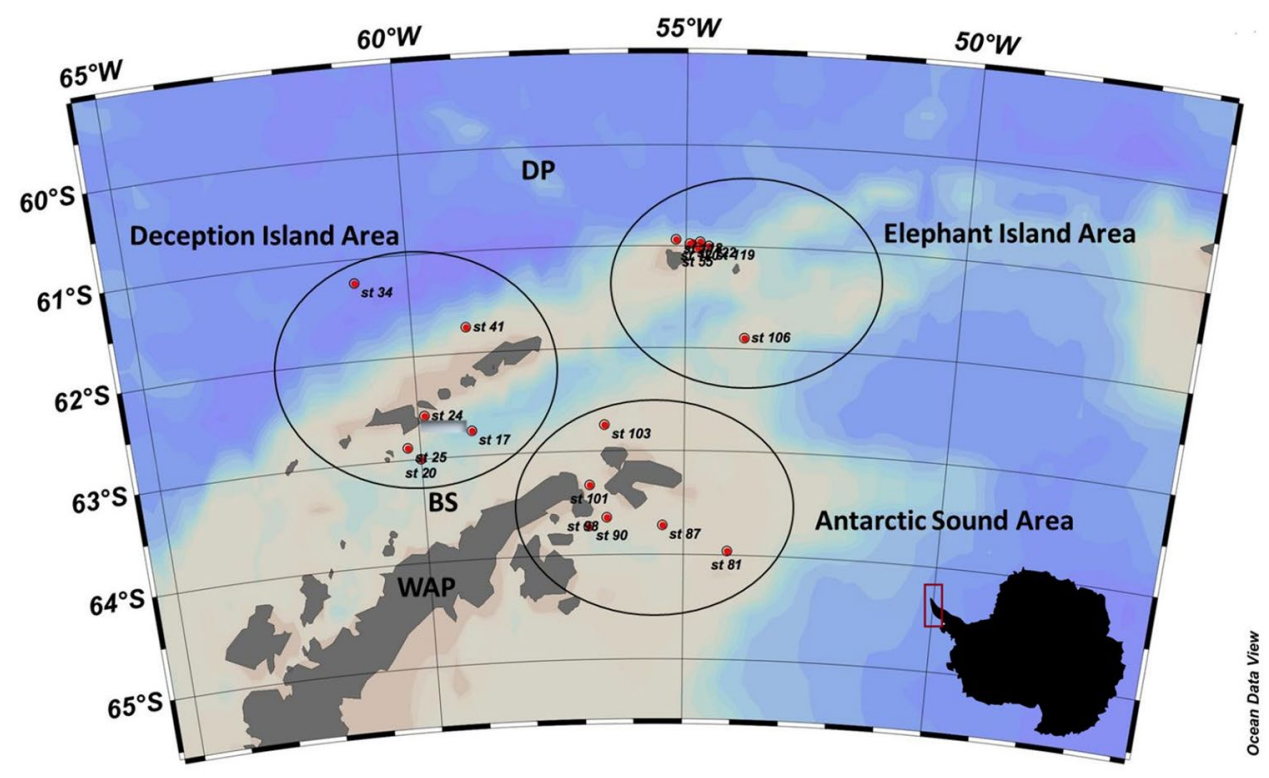

temperature, conductivity, oxygen and chlorophyll fluorometer sensors.

At each depth, 20-L of water were collected and immediately reverse-filtered through a $10-\mu \mathrm{m}$ mesh in order to reduce the volume to $250 \mathrm{~mL}$. Once reduced, the samples were immediately fixed with buffered formaldehyde (final concentration 4\%). Subsurface (0-30 m) qualitative MZP samples were additionally taken using a $20-\mu \mathrm{m}$ mesh net, fixed and stored as previously described with the aim of accurate studies on the taxonomy.

\section{Microzooplankton analysis}

Subsamples $(50 \mathrm{~mL})$ of sea water were examined in a settling chamber using an inverted microscope (Leica DMI 3000B) equipped with phase-contrast and bright-field illumination (magnification 200x), according to the Utermöhl method (1958). The entire surface of the chamber was examined. In total, 80 sea water samples were analysed. For MZP qualitative and quantitative analyses, we considered organisms with dimensions between 20 and $200 \mu \mathrm{m}$ size. Only for three tintinnids genera (Cymatocylis, Laackmanniella and Salpingella) bigger dimensions were included.

Among the MZP community, we considered: Ciliophora, Myzozoa, Foraminifera, Radiozoa, Cercozoa and the first stage of micrometazoan larvae. In this paper, Ciliophora are cited as tintinnids (Order Choreotrichida) and as aloricate ciliates (Orders Oligotrichida and Haptorida), Myzozoa are cited as heterotrophic dinoflagellates (Orders Gymnodiniales and Peridiniales) and Foraminifera, Cercozoa and Radiozoa are included in the group of other protozoa. The identification to these groups were based on the descriptions of Alder (1999), Petz (2005) and Petz et al. (1995) for the
Ciliophora, Balech (1976) and McMinn and Scott (2005) for the Myzozoa, Kemle-von Mücke and Hemleben (1999) for the Foraminifera, Kling and Boltovskoy (1999) for the Cercozoa and Radiozoa, and Larik and Westheide (2006) for the micrometazoans. In our samples, we did not consider Codonellopsis gaussi and Codonellopsis glacialis as morphotype, as well as Cymatocylis convallaria and Cymatocylis drygalskii as synonymous, but we kept the difference between the species according to Petz (2005).

Empty loricae were not differentiated from filled ones, because the tintinnid protoplasts are attached to the loricae by fragile strands that can easily detach during collection and fixing of the samples (Alder 1999). Heterotrophic dinoflagellates were selected based on previous studies (Lessard 1991). Only for Gyrodinium sp. we could not confirm the heterotrophy by literature, although their contribution to the total MZP abundance was smaller as $4 \%$.

For each taxon, the biomasses were estimated by measuring the linear dimensions of each organism using an eyepiece scale and relating the individual shapes to standard geometric figures. Because of the considerable and continuous variability in lorica length, for the cell volume calculation, we grouped Cymatocylis drygalskii in three different classes, according to the total lorica length (tll) and the length of the antapical horn (ahl). Class 1: tll $\leq 200 \mu \mathrm{m}$ and ahl $<10 \mu \mathrm{m}$; class 2 : tll $=200-230 \mu \mathrm{m}$ and ahl $=10-30 \mu \mathrm{m}$; class 3 tll $=230-310 \mu \mathrm{m}$ and ahl $=30-110 \mu \mathrm{m}$. Cell volumes were converted to carbon values using the appropriate formulae and conversion factors, as: tintinnids, pg C cell ${ }^{-1}=\mu \mathrm{m}^{3} \times 0.053+444.5$ (Verity and Langdon 1984); aloricate ciliates, pg C cell ${ }^{-1}=\mu \mathrm{m}^{3} \times 0.14$ (Putt and Stoecker 1989); heterotrophic dinoflagellates, pg C cell $^{-1}=\mu \mathrm{m}^{3} \times 0.11$ (Edler 1979); others protozoans, pg C 
cell $^{-1}=\mu \mathrm{m}^{3} \times 0.089($ Gifford and Caron 2000); micrometazoans, pg C cell ${ }^{-1}=\mu \mathrm{m}^{3} \times 0.08$ (Beers and Stewart 1970).

\section{Statistical analysis}

To test the community composition and the similarity pattern presented by the main MZP taxa, the samples were analysed on the base of the different areas (DI, EI, AS). The factor "zone" was also considered dividing samples collected in the photic zone from the once collected in the aphotic one. The distinction between photic and aphotic was carried out based on sampling depths using fluorescence profile as proxy: we considered in the photic zone surface, DCM and $100 \mathrm{~m}$, while samples collected at depths $\geq 200$ $\mathrm{m}$ were considered in the aphotic zone. Multivariate analyses were based on Bray-Curtis similarities index (Bray and Curtis 1957), as calculated from the square-root-transformed abundance data. PERMANOVA analysis was carried out to test the effect of the considered variable on the community structure. PCO ordination, cluster analysis and SIMPER analysis were useful to detect which taxa were more involved in the communities' similarity pattern. The analyses were conducted using the PRIMER V.7 software (Clarke and Gorley 2015), and the significance level for all statistical tests was set at $5 \%$.

\section{Results}

\section{Hydrographic setting}

The area surveyed was characterized by mixing processes (Moffat and Meredith 2018; Llanillo et al. 2019). Water temperature varied from $-1.85^{\circ} \mathrm{C}$ (Antarctic Sound, St. 81 at $10 \mathrm{~m}$ ) to $2.05^{\circ} \mathrm{C}$ (Deception Island, St. 34 at $500 \mathrm{~m}$ ) (Fig. 2). The water temperature in the whole water column within the Antarctic Sound area was below $-1{ }^{\circ} \mathrm{C}$ compared to higher temperatures sampled in the other two areas (Fig. 3).

In the area investigated salinity varied from 33.71 (St.34 at $7 \mathrm{~m}$ ) to 34.6 (St. 34 at $500 \mathrm{~m}$ ) (Fig. 2). A surface mixed water mass, characterized by similar values for temperature and salinity, were analyzed at all stations. At Deception Island a mixed layer went down close to $100 \mathrm{~m}$ (Fig. 3), this could be seen in equal value for salinity and temperature in the surface water and at depth of $50 \mathrm{~m}$. In the Deception Island area, all stations except station 34, presented a clear surface mixed layer, indicating the occurrence of two water masses in the upper $200 \mathrm{~m}$. Station 34, offshore north of South Shetland Island, presented three water masses: the Shelf Water with salinity below 34 and temperature of $1{ }^{\circ} \mathrm{C}$, the Antarctic Surface Water (AASW) with temperature between 0 and $1{ }^{\circ} \mathrm{C}$ and salinity around 34, and the Antarctic
Intermediate Water (AAIW) with higher temperature and salinity.

At the majority of stations in the Elephant Island area two water masses were detected, one at the surface showing the typical response to atmospheric cooling processes, and a mixed deeper layer (Fig. 3). The Antarctic Sound stations presented a typical profile for a shelf sea in an ice-covered region, characterized by WSW (Western Shelf Water), with low temperature $\left(<-1.5^{\circ} \mathrm{C}\right)$ and salinity between 34.2 and 34.8 (Fig. 3).

The chlorophyll fluorescence at DMC (Fig. 2 top right) showed highest concentrations within the Deception Island sampling area. In the center of the Bransfield Strait and at St. 34 was up to 5 (arb. units) and 4 (arb. units), respectively, while the lowest concentration within depth of DMC was detected close to Antarctic Sound area, close to zero (arb. units). All the area south to Antarctic Sound (northwestern Weddell Sea) showed very low values, as well as St. 106, offshore southern to Elephant Island (Figs. 2 and 3).

\section{Microzooplankton abundances}

The total MZP abundance ranged from 3 (Deception Island area, St. 17 at $500 \mathrm{~m}$ ) to 109 ind. $\mathrm{L}^{-1}$ (Antarctic Sound, St. 87 at $100 \mathrm{~m}$ ) (Table 2). Tintinnids were the most abundant group (up to 103 ind. $\mathrm{L}^{-1}$ ) followed by heterotrophic dinoflagellates (up to $64.5 \mathrm{ind} . \mathrm{L}^{-1}$ ). Aloricate ciliates presented values below 29 ind. $\mathrm{L}^{-1}$ and micrometazoans below 14 ind. $\mathrm{L}^{-1}$, other protozoans presented values $<7$ ind. $\mathrm{L}^{-1}$. The three areas presented different abundances (Table 2). Antarctic Sound showed the highest abundance values and Deception Island the lowest ones. In Antarctic Sound and Elephant Island, the total abundance reflected the tintinnids numbers while in Deception Island area heterotrophic dinoflagellates showed the highest value (Table 2).

In the Antarctic Sound, the highest tintinnids abundance corresponded to the lowest micrometazoans values, whereas in the Deception Island sampling area, the opposite was the case. The Elephant Island area showed high values for both tintinnids and micrometazoans. The Antarctic Sound area showed on average the lowest and Elephant Island area the highest copepod nauplii abundance with $1.2 \pm 1.6$ ind. $\mathrm{L}^{-1}$ and $3.5 \pm 2.4$ ind. $\mathrm{L}^{-1}$, respectively.

Deception Island area showed $44 \%$ of tintinnids and the rest were heterotrophic dinoflagellate, aloricate ciliates and micrometazoans (Fig. 4). In percentage, the Elephant Island and Antarctic Sound areas presented a similar composition. In particular, tintinnids reached, respectively, $73 \%$ and $83 \%$ of the MZP composition, with all the other groups varying between 20 and 30\% (Fig. 4).

At Antarctic Sound, the maximum abundance was registered at $100 \mathrm{~m}$, at Deception Island and Elephant Island, the maxima abundances were present at surface and DMC 


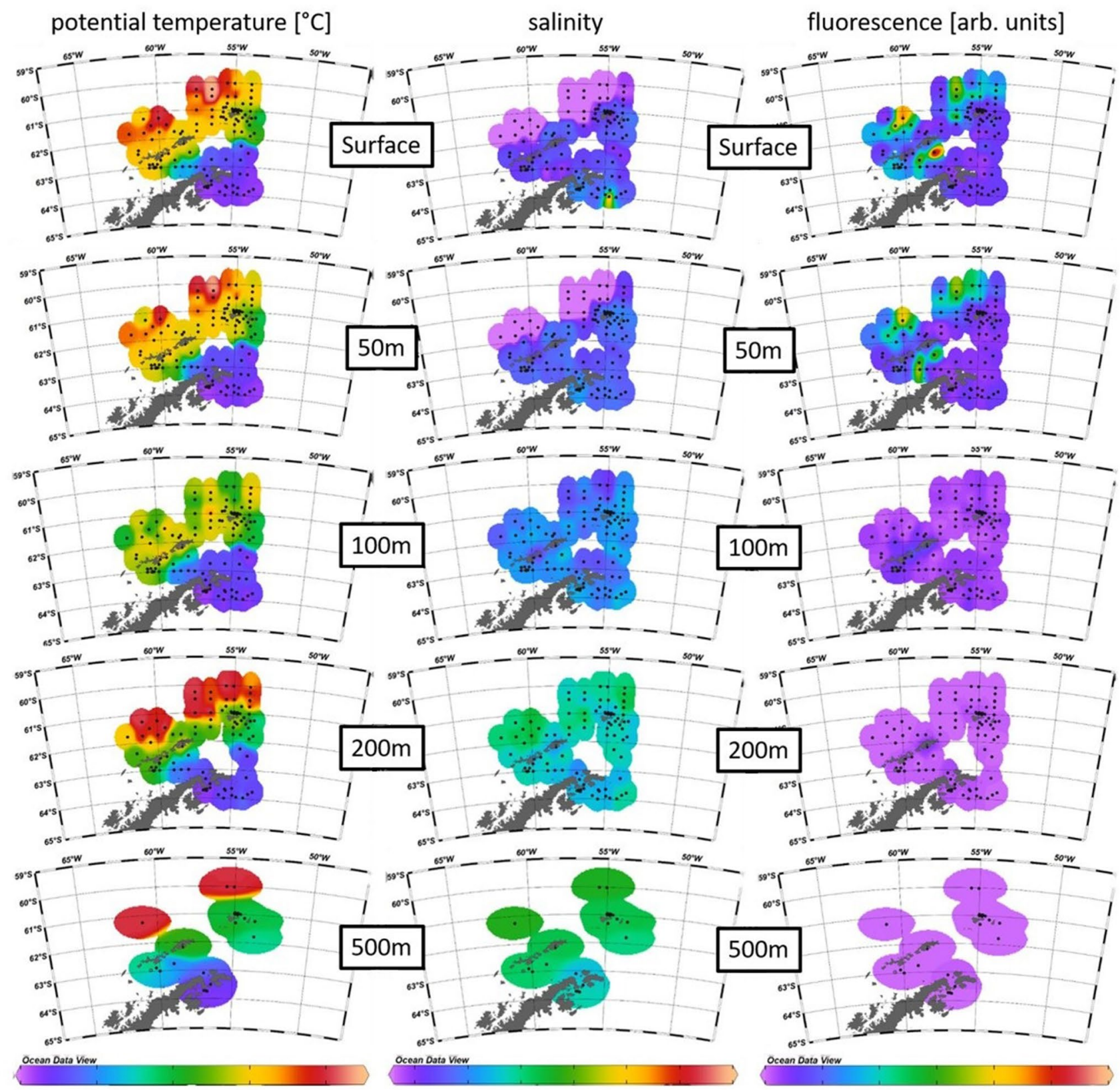

Fig. 2 Map of potential water temperature $\left({ }^{\circ} \mathrm{C}\right.$; left column), salinity (middle column) and fluorescence (arb. units; right column) at the research area given for defined sampling water depths. Depths lev-

depth, decreasing with the depths. The different groups showed a different behavior according to the depth. Generally, tintinnids showed maxima at the surface (Deception Island and Elephant Island areas) and DMC (Antarctic Sound), while the other groups did not present high variation with greater depth (Fig. 4). Heterotrophic dinoflagellates were abundant at the surface in the Elephant Island area (Fig. 4), while aloricate ciliates were abundant at DMC and $100 \mathrm{~m}$ in the Deception Island area. els are surface layer, $50 \mathrm{~m}$ water depth (nearly DMC), $100 \mathrm{~m}$ water depth, $200 \mathrm{~m}$ water depth and $500 \mathrm{~m}$ water depth from top to bottom

\section{Microzooplankton species composition}

The analysis of the composition of the MZP community identified 47 taxa (Table 3).

Among the most widespread species, only four ever individually constituted more than $84 \%$ of the tintinnids population. The genera Codonellopsis with the species balechi (Fig. 5a) and glacialis (Fig. 5b), and Cymatocylis 

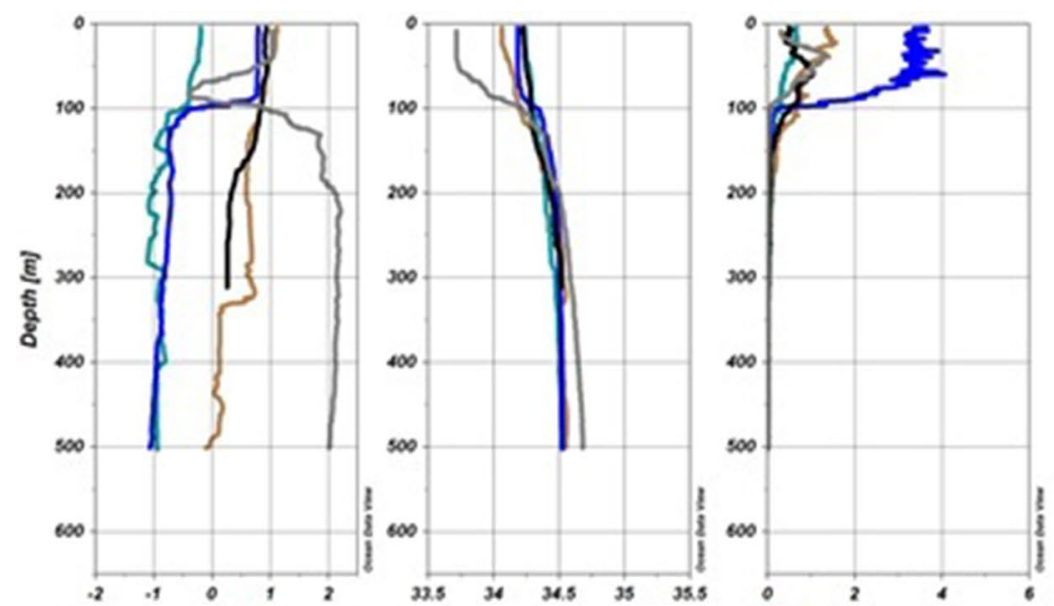

Area 1: Deception Island
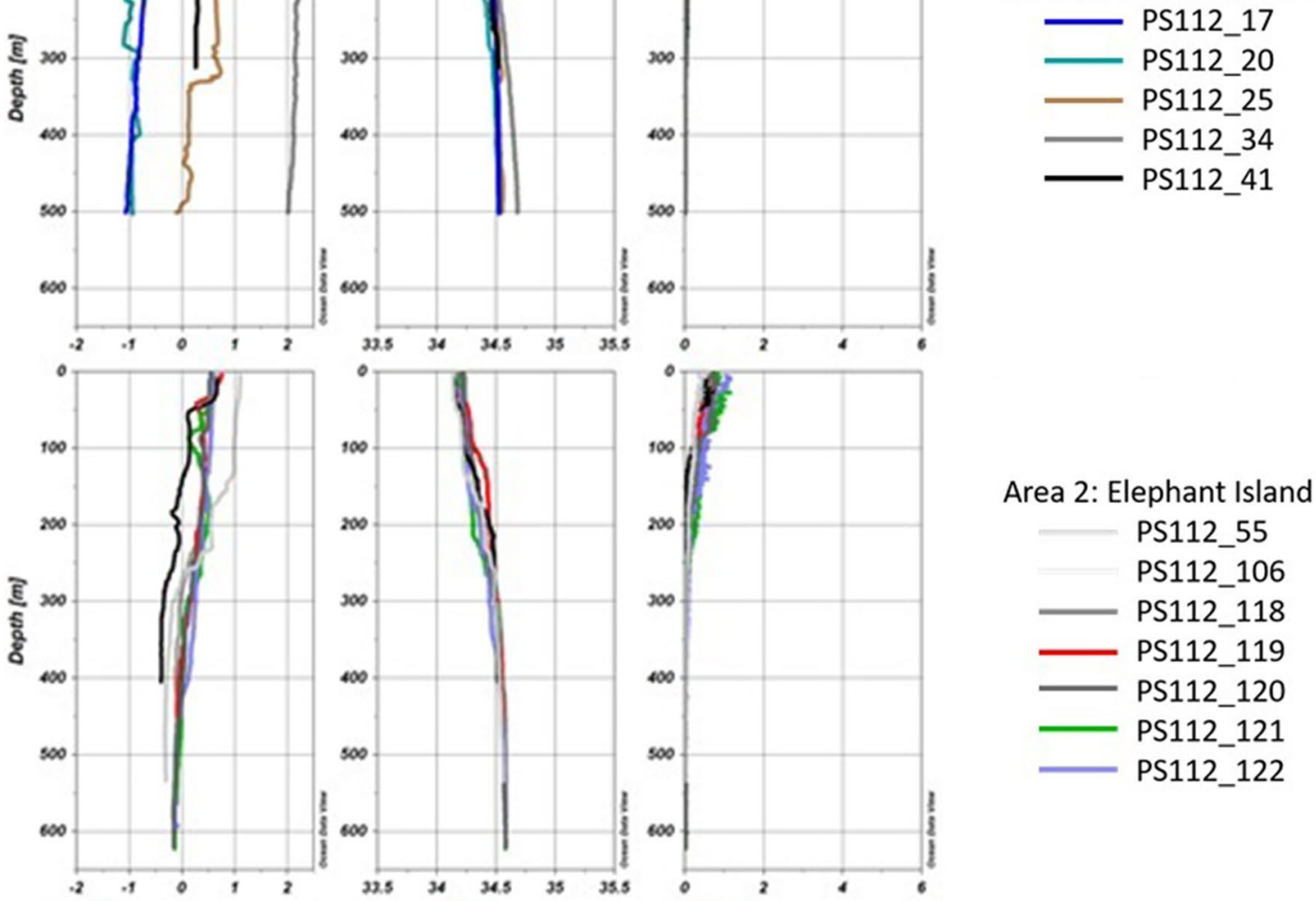

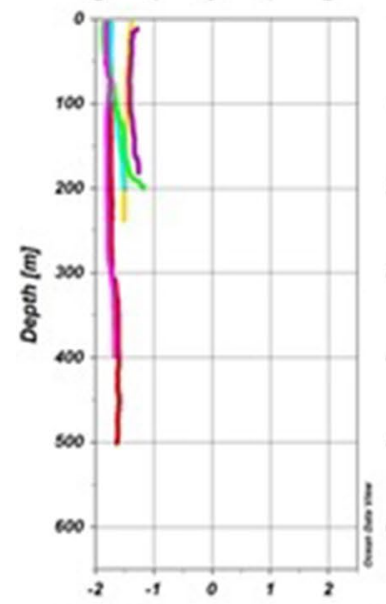

potential temperature $\left[{ }^{\circ} \mathrm{C}\right]$

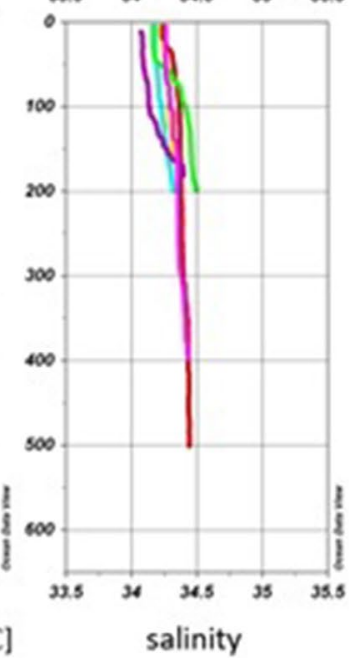

Fig. 3 Profiles of potential temperature $\left({ }^{\circ} \mathrm{C}\right.$; left column), salinity (middle column) and fluorescence (arb. units; right column) for all stations according to Table 1. Stations reflecting defined areas: Area

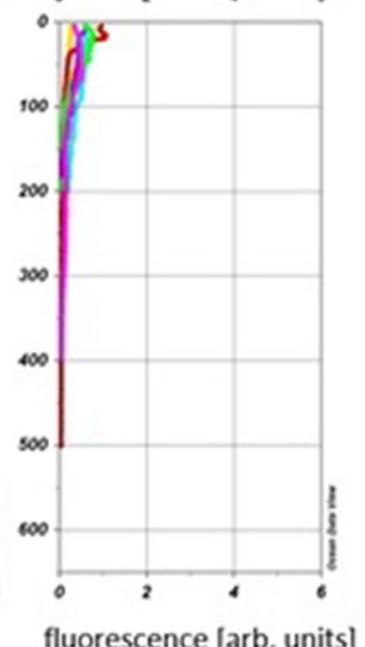

1-Deception Island (upper line), Area 2-Elephant Island (middle line) and Area 3-Antarctic Sound (lower line)

drygalskii from 0.6 to 14.3 ind. $\mathrm{L}^{-1}$. Cymatocylis vanhöffeni (Fig. 5g), Cymatocylis calyciformis (Fig. 5h), L. naviculaefera (Fig. 5i), Amphorides laackmanni (Fig. 51) and Salpingella sp. were on average always $<1$ ind. $\mathrm{L}^{-1}$. Codonellopsis gaussi, L. prolongata and 
Table 2 Abundance of the different groups in the three areas

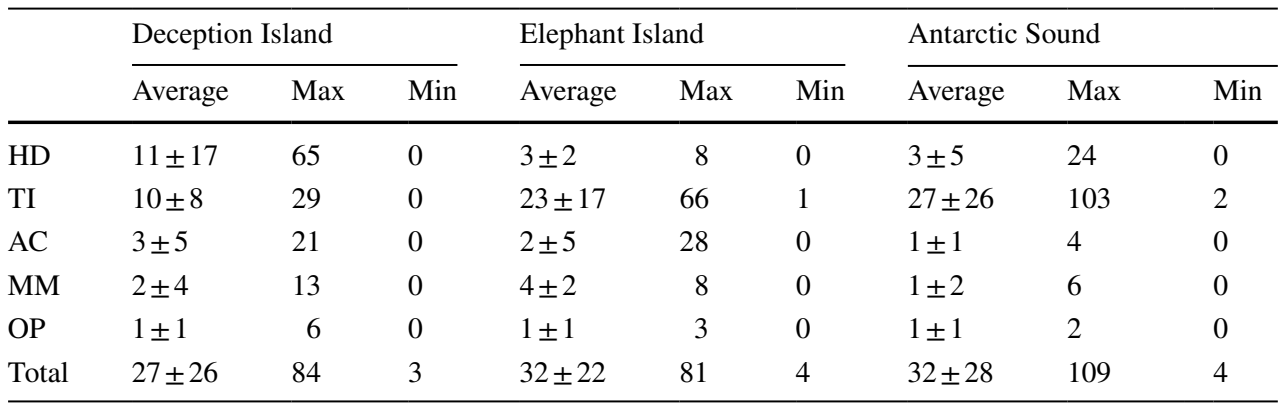

$H D$ heterotrophic dinoflagellates, $T I$ tintinnids, $A C$ aloricate ciliates, $M M$ micrometazoans, $O P$ other Protozoa

\section{Deception Island}
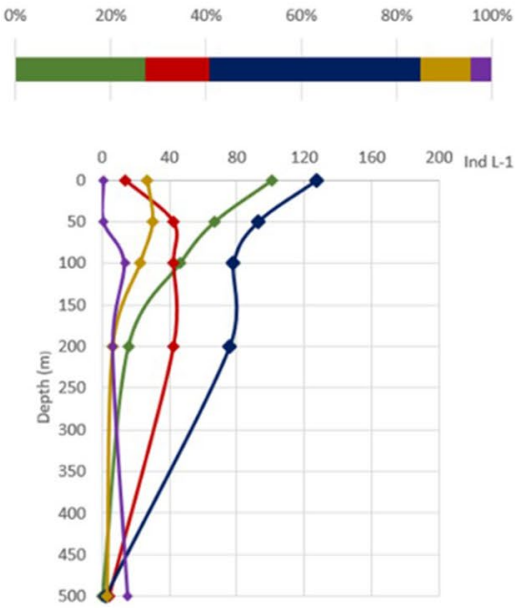

Elephant Island
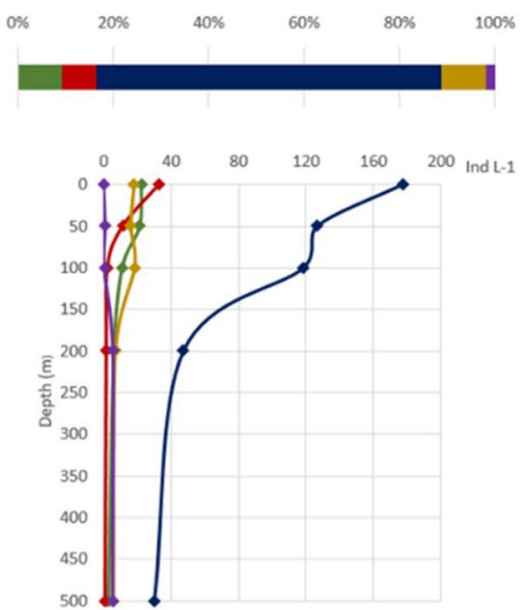

Aloricate Ciliates
Antarctic Sound
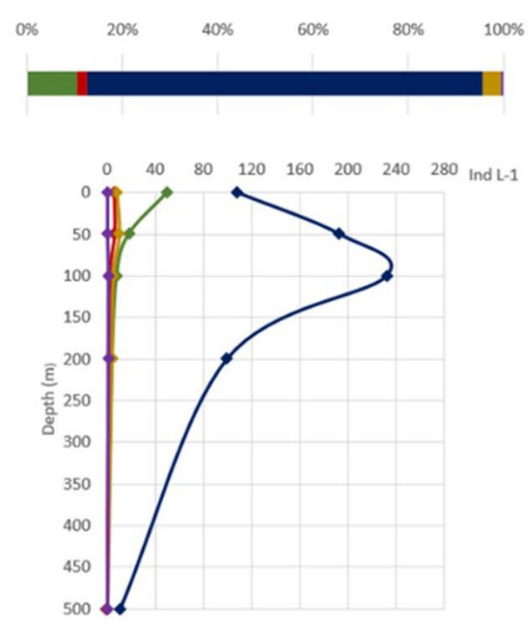

Micrometazoans

Fig. 4 Percentage composition of MZP and vertical abundance in the three areas: Deception Island, Elephant Island and Antarctic Sound

Epiplocyloides antarctica were very rare with an average abundance $<0.07$ ind. $\mathrm{L}^{-1}$.

In the Deception Island and Elephant Island area, the most abundant species was Codonellopsis glacialis. This species presented a slightly agglutinated lorica with bulletshaped and hyaline annulated short collar that correspond to the width. Codonellopsis glacialis in our study was dominant in the stations north to $63^{\circ} \mathrm{S}$.

In the Antarctic Sound area, Codonellopsis balechi was the dominant tintinnid species. It presented an ovoid shape lorica with agglutinated mineral particles, and a short annulated hyaline collar.

In the Deception Island area, the second abundant species was Cymatocylis convallaria. This species presented a hyaline lorica, antapically blunt to pointed, and an outer collar bent downwards.

In our samples, Cymatocylis drygalskii presented a wall hyaline cylindrical shape with different length of the lorica, mainly due to the antapical horn. The collar rim was serrated and bent downwards, and the external diameter of the bowl was quite constant and poorly correlated with lorica length.

Among rare tintinnids Cymatocylis vanhöffeni (Fig. 5g) presented a bowl elongate hyaline lorica with the anterior portion of lorica striated. The rim was serrated without an outer collar and external opening diameter quite constant.

Cymatocylis calyciformis presented a hyaline bowl cushaped lorica (Fig. 5h) with a long antapical horn and a collar bent downwards. In our samples, this species was present only in four stations (St. 34, 106, 119 and 120) north to $62^{\circ} \mathrm{S}$.

Laackmanniella naviculaefera presented a cylindrical annulated hyaline lorica (Fig. 5i) with a very constant opening diameter similar to the one of Laackmanniella prolongata which however presented a greater length. Amphorides laackmanni showed a hyaline wall with few longitudinal fins (Fig. 51) and a very short body. This species is not as peculiar to Antarctic waters as the genus Salpingella. The latter showed the highest abundance at the surface of St. 34 . 
Table 3 Taxa observed during the sampling period

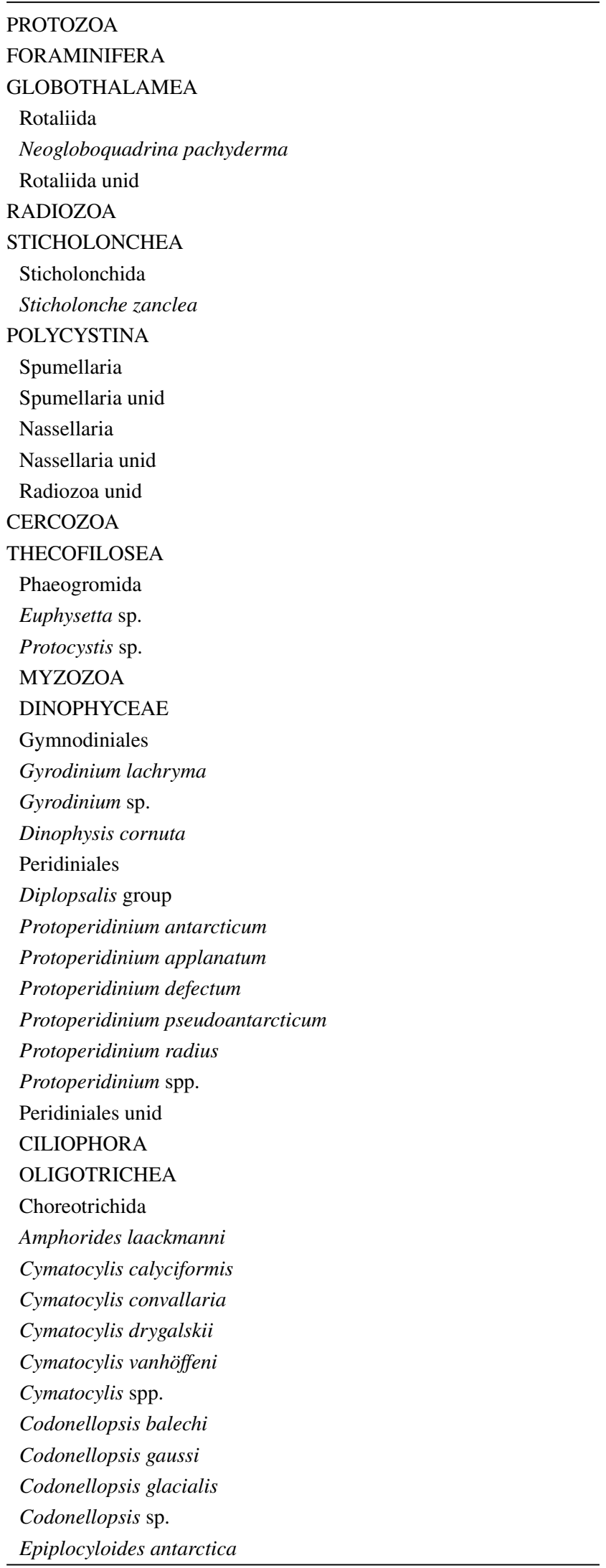

Table 3 (continued)

Laackmanniella naviculaefera
Laackmanniella prolongata
Salpingella sp.
Choreotrichida unid
Oligotrichida
Spirostrombidium sp.
Strombidium spp.
Oligotrichida unid
LITOSTOMATEA
Cyclotrichiida
Cyclotrichiida unid
Haptorida
Didinium gargantua
Haptorida unid
PHYLLOPHARYNGEA
Chlamydodontida
Gymnozoum sympagicum
Chlamydodontida unid
Ciliophora unid
METAZOA
ARTHROPODA
HEXANAUPLIA
COPEPODA
Copepods (nauplius)
Larvae unid
Eggs unid
MOLLUSCA
GASTROPODA
Pteropoda

Epiplocyloides antarctica and Codonellopsis gaussi were present in very small numbers. The shape of the first one resembled a small Cymatocylis and was present at subsurface layers in three stations (St. 34, St. 119 and St. 122) north to $61.5^{\circ} \mathrm{S}$. Codonellopsis gaussi presented cylindrical lorica variable in length and an annulated collar, and a bowl not uniformly dilated in the middle with agglutinated foreign particles. This species was detected only in offshore stations (St 34, St 106 and St 119) north to $62^{\circ} \mathrm{S}$.

All the tintinnids detected showed a wide range in size, especially in the lorica length (Table 5).

Among the aloricate ciliates, raptorial litostomes were well represented. The genus Gymnozoum was found in almost all the samples with the species G. sympagicum. Also Strombidium sp. and Didinium gargantua were present at many sampling stations.

The heterotrophic dinoflagellates were found at lower abundances, with the genera Protoperidinium and Gyrodinium. Among Protoperidinium five species were determined: antarcticum, applanatum, defectum, pseudoantarcticum and 


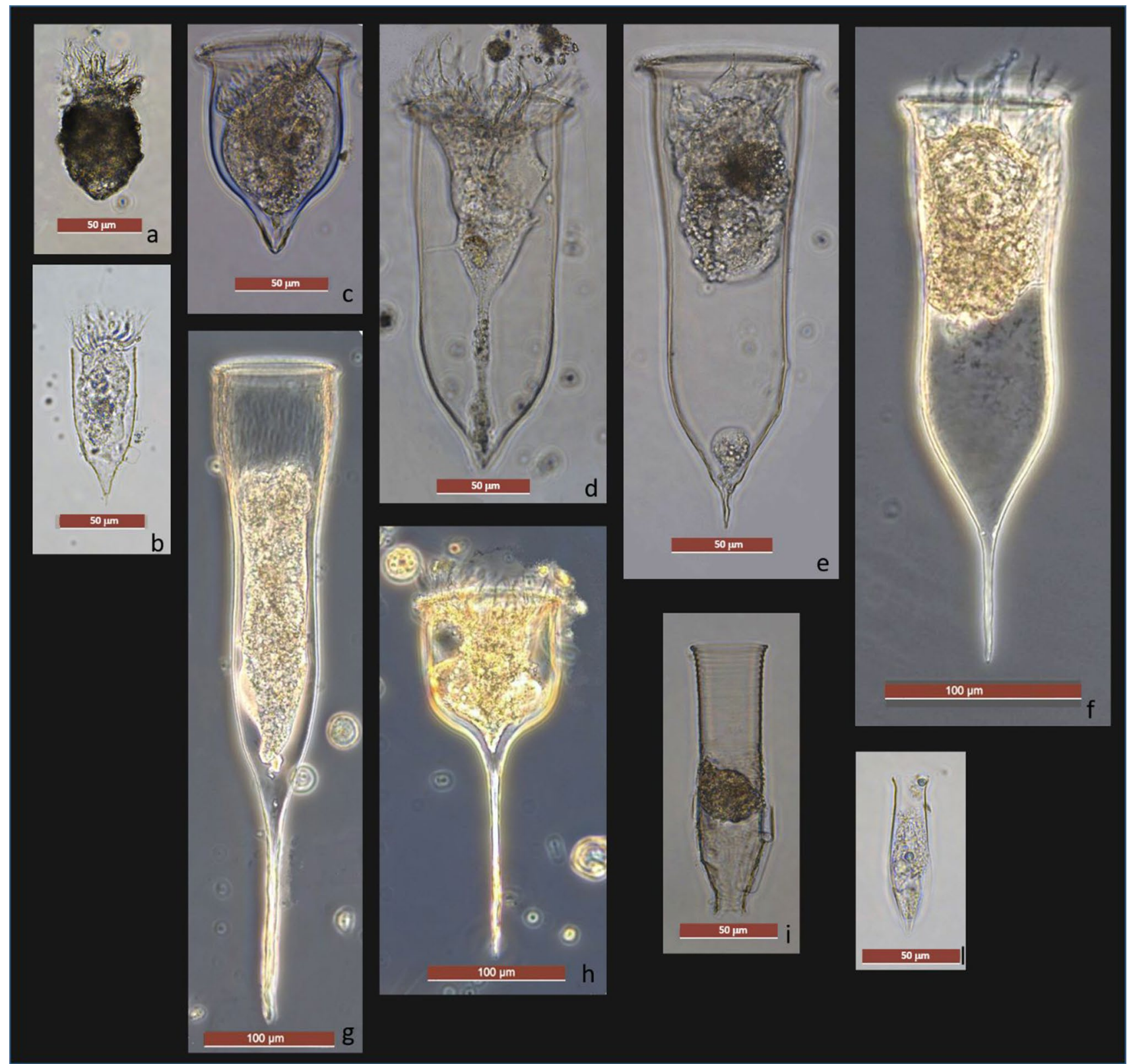

Fig. 5 Tintinnid species: a Codonellopsis balechi, b Codonellopsis glacialis, c Cymatocylis convallaria, d Cymatocylis drygalskii class 1, e Cymatocylis drygalskii class 2, $\mathbf{f}$ Cymatocylis drygalskii class 3 ,

radius. Among Gyrodinium only G. lachryma was determined. In particular, at the subsurface of St. 17 a maximum value of 51 ind. $\mathrm{L}^{-1}$ was registered, followed by stations 25 and 34 with respective values at the upper water column (20 $\mathrm{m}$ and $7 \mathrm{~m}$ depth) of 22 and 23 ind. $\mathrm{L}^{-1}$.

The naupliar stage of copepods were present in almost all the samples while the other protozoa, such as Radiozoa and Cercozoa, were very rare and generally found in the deeper layers. Foraminifera were present only in the northern offshore station of Deception Island area (St. 34). g Cymatocylis vanhöffeni, $\mathbf{h}$ Cymatocylis calyciformis, i Laackmanniella naviculaefera, $\mathbf{I}$ Amphorides laackmanni

\section{Microzooplankton biomass}

The MZP biomasses ranged from $0.009 \mu \mathrm{g} \mathrm{C} \mathrm{L}^{-1}$ (St. 20 at 0 $\mathrm{m})$ to $2.55 \mu \mathrm{g} \mathrm{C} \mathrm{L}{ }^{-1}$ (St. 55 at $0 \mathrm{~m}$ ). Elephant Island area presented the higher average biomass value, for both the photic and aphotic zone, $1.04( \pm 0.29) \mu \mathrm{g} \mathrm{C} \mathrm{L}^{-1}$ and $0.23( \pm 0.26)$ $\mu \mathrm{g} \mathrm{C} \mathrm{L}{ }^{-1}$, respectively. The tintinnids' carbon represented up to $88 \%$ (Antarctic Sound) and 79\% (Elephant Island) of the overall MZP biomass. The higher carbon values in Elephant Island area was due to the bigger dimensions of 
Table 4 Tintinnids species list, including the average mean abundance (ind. $\mathrm{L}^{-1}$ ): $+=0.01-$ $0.1 ;++=0.2-0.9 ;+++=1-9$; the frequency and occurrence

Table 5 Tintinnids size range $(\mu \mathrm{m})$

\begin{tabular}{llcc}
\hline Tintinnid taxa & Abundance & Frequency & Occurrence \\
\hline Amphorides laackmanni (Jörgensen) Strand 1928 & ++ & 13 & 0.74 \\
Cymatocylis calyciformis (Laackmann) Laackmann 1907 & ++ & 8 & 1.64 \\
Cymatocylis convallaria Laackmann 1910 & +++ & 55 & 9.91 \\
Cymatocylis drygalskii (Laackmann) Laackmann 1907 & +++ & 80 & 7.90 \\
Cymatocylis vanhöffeni (Laackmann) Laackmann 1910 & ++ & 80 & 4.63 \\
Cymatocylis spp. Laackmann 1907 & ++ & 6 & 0.20 \\
Codonellopsis balechi Hada 1970 & +++ & 73 & 41.38 \\
Codonellopsis gaussi Laackmann 1907 & + & 5 & 0.35 \\
Codonellopsis glacialis Laackmann 1909 & +++ & 58 & 24.73 \\
Codonellopsis sp. Jörgensen 1924 & ++ & 80 & 2.63 \\
Epiplocyloides antarctica Balech 1962 & + & 3 & 0.07 \\
Laackmanniella naviculaefera (Laackmann 1907) Kofoid \& & +++ & 44 & 4.96 \\
Campbell 1929 & & & \\
Laackmanniella prolongata Laackmann 1907 & + & 6 & 0.21 \\
Salpingella sp. Jörgensen 1924 & ++ & 18 & 0.85
\end{tabular}

\begin{tabular}{lclc}
\hline Tintinnid species & Length lorica $(\mu \mathrm{m})$ & $\begin{array}{l}\text { Opening diameter } \\
(\mu \mathrm{m})\end{array}$ & $\begin{array}{l}\text { Antapical } \\
\text { horn }(\mu \mathrm{m})\end{array}$ \\
\hline Amphorides laackmanni & & $16-19$ & - \\
Cymatocylis calyciformis & $55-78$ & $95-122$ & $86-203$ \\
Cymatocylis convallaria & $187-312$ & $86-102$ & - \\
Cymatocylis drygalskii & $106-133$ & $73-110$ & $8-109$ \\
Cymatocylis vanhöffeni & $183-309$ & $87-100$ & $94-230$ \\
Codonellopsis balechi & $322-547$ & $31-36$ & - \\
Codonellopsis glacialis & $70-86$ & $31-36$ & - \\
Laackmanniella naviculaefera & $62-81$ & $34-39$ & - \\
Laackmanniella prolongata & $128-172$ & $34-39$ & - \\
Salpingella sp. & $270-310$ & $20-25$ & -
\end{tabular}

Codonellopsis glacialis, compared to Codonellopsis balechi, the most common species in Antarctic Sound. Only in Deception Island area aloricate ciliates (22\%), heterotrophic dinoflagellates (32\%) and micrometazoans (24\%) contributed to the Carbon values. In general, the higher biomasses were due to the large size of the tintinnids Codonellopsis glacialis, Codonellopsis balechi, Cymatocylis drygalskii and Cymatocylis convallaria and to the aloricate ciliates Haptorida. The naupliar stages of copepods also contributed to the total amount of carbon, especially in the Deception (18\%) and Elephant Island (15\%) areas.

\section{Microzooplankton community structure}

Concerning the MZP composition in the study area, PERMANOVA analyses detected a significant effect $(p<0.001)$ of factor "zone" (photic and aphotic) in shaping the MZP community.
In the PCO plot, the samples collected in the photic layer were divided from the samples collected in the aphotic layer along the first axis. Overlaying the vector of the variable that most influenced the PCO ordination (correlation $>0.6$ ), it was possible to notice that in the aphotic zone samples were characterized by the presence of the genus Protocystis, while the samples collected in the photic zone were characterized by dinoflagellate, specifically the dinoflagellates Gyrodinium and Protoperidinium and a higher abundance of tintinnids with the genera Cymatocylis and Codonellopsis (Fig. 6).

PERMANOVA analyses also detected a significant effect $(p<0.001)$ of geographical area on the community structures. The PCO ordination showed how the samples from the Deception Island area had higher variability in the community structure and were widely distributed in the plot of the analysis, while the samples collected in the Antarctic Sound were separated from the Elephant Island samples along the second axis. The most varied on the second axis were Codonellopsis balechi and Cymatocylis drygalskii (Fig. 7). 


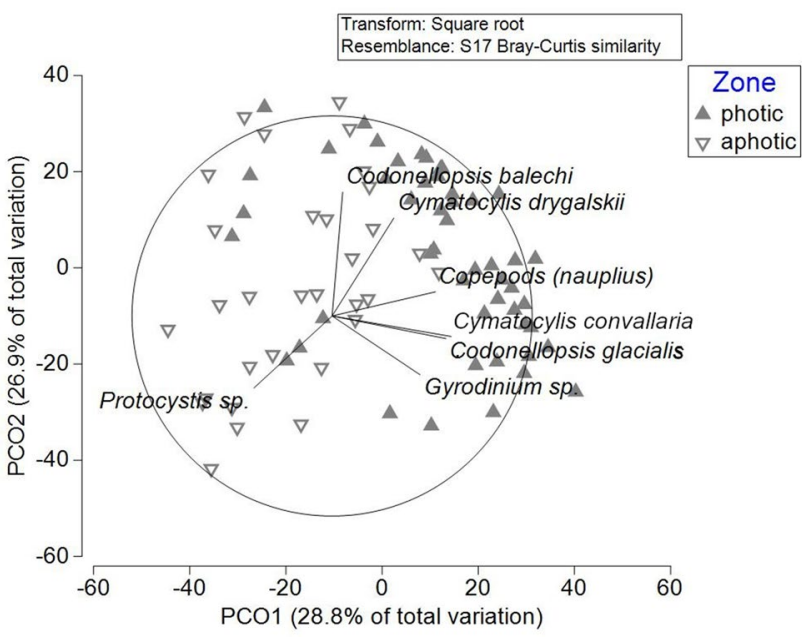

Fig. 6 The PCO plot shows the ordination of the samples collected in the photic (filled triangle) and aphotic layers (unfilled triangle)

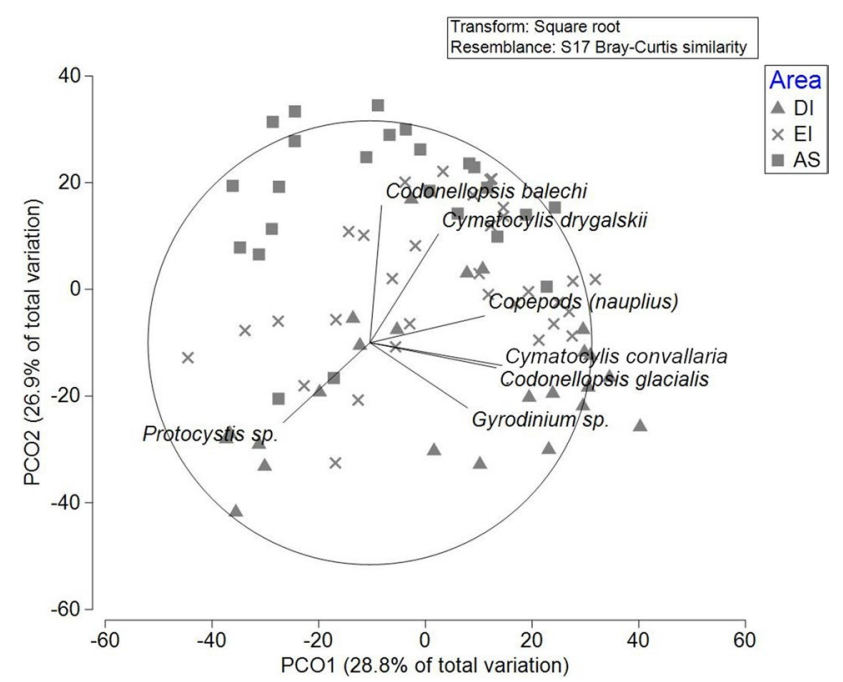

Fig. 7 The PCO plot shows the ordination of the samples collected in the three different areas. Filled triangle: Deception Island; cross: Elephant Island; square: Antarctic Sound

Analyzing the tintinnid spatial distribution with the SIMPER tool, we were able to identify the species and abundances for each of the three different geographical areas (Table 6). Antarctic Sound showed the highest presence of Codonellopsis balechi and L. naviculaefera, while Elephant Island was characterized by higher abundance of Codonellopsis glacialis, Cymatocylis convallaria and Cymatocylis vanhöffeni. The samples collected in the Deception Island area were characterized by lower abundances of Codonellopsis glacialis, Codonellopsis balechi and Cymatocylis convallaria.

Analyzing the matrix built on the similarity index among species, it was possible to highlight groups of related species
Table 6 Simpler analysis results

\begin{tabular}{lllll}
\hline Species & $\begin{array}{l}\text { av. } \\
\text { abund. }\end{array}$ & $\begin{array}{l}\text { av. } \\
\text { sim. }\end{array}$ & sim. SD & contrib.\% \\
\hline Group DI & & & & \\
Codonellopsis glacialis & 1.42 & 9.84 & 0.75 & 30.83 \\
Codonellopsis balechi & 0.91 & 8.79 & 0.87 & 27.55 \\
Cymatocylis convallaria & 0.87 & 5.40 & 0.61 & 16.94 \\
Average similarity within group: 31.90 & & & \\
Group EI & & & & \\
Codonellopsis balechi & 2.19 & 15.08 & 2.21 & 28.50 \\
Codonellopsis glacialis & 2.27 & 12.04 & 1.47 & 22.75 \\
Cymatocylis convallaria & 1.48 & 8.96 & 1.34 & 16.92 \\
Cymatocylis vanhöffeni & 0.97 & 7.00 & 1.41 & 13.22 \\
Average similarity within group: 52.93 & & & \\
Group AS & & & & \\
Codonellopsis balechi & 3.69 & 28.42 & 2.13 & 57.15 \\
Laackmanniella navicu- & 1.17 & 7.64 & 1.24 & 15.36 \\
$\quad$ laefera & & & &
\end{tabular}

Average similarity within group: 49.73

av. abund. average abundance, $a v$. sim. average similarity, sim. $S D^{-1}$ similarity Standard Deviation ${ }^{-1}$, contrib.\%contribution \%

with significant $(p<0.05)$ covariation (red in Fig. 8). The detected pattern showed a group of three species with the same abundance trend and the same presence/absence evidence (Codonellopsis gaussi, Cymatocylis calyciformis and Salpingella sp.).

\section{Discussion}

The importance of MZP in the marine food web as grazers (Calbet and Landry 2004), and as food supply for higher trophic levels (Schmidt et al. 2006), is widely recognized. The Western Antarctic Peninsula is a region with a high rate of warming and ice melt (Ducklow et al. 2012). The regional warming has differentially affected the WAP, with a warmer sub-Antarctic climate invading the northern part of the Peninsula, and the typically cold Antarctic climate still present in the southern part of the Peninsula (Ducklow et al. 2012). The plankton communities in the area are affected by modified physico-chemical and hydrological characteristics of the water column (Garcia et al. 2016) and, in this new balance, MZP can play a crucial role in the modified trophic webs.

\section{Microzooplankton abundance}

In the present study, MZP showed a low abundance (average 30.4 ind. $\mathrm{L}^{-1}$ ) and biomass (average $0.45 \mu \mathrm{g} \mathrm{C} \mathrm{L}^{-1}$ ) compared to other Antarctic areas, such as the Weddell Sea and the Ross Sea (Boltovskoy and Alder 1992; Fonda 


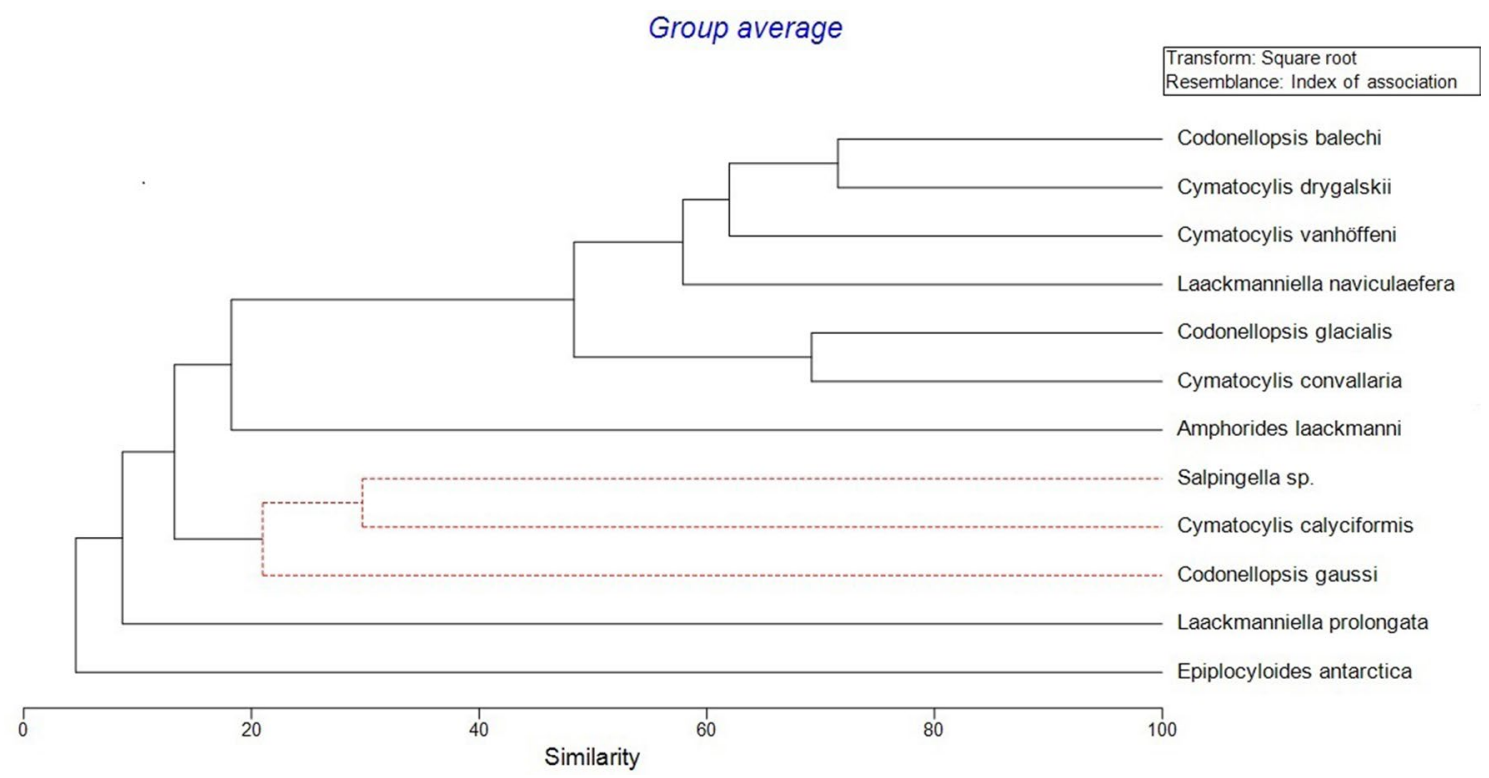

Fig. 8 Cluster analyses on species similarity matrix. The red group was significantly tested by Simprof analyses $(\mathrm{p}<0.5)$

Umani et al. 1998; Monti and Fonda Umani 2000). The low abundance along the WAP was already highlighted by other authors that ascribed it to a general response of the plankton community to regional enhancements associated with variations in sea ice advance/retreat and glacier melting rhythms (Alder and Boltovskoy 1991; Cabet et al. 2005; Thompson and Alder 2005).

In particular, in the northern WAP, due to the glacial meltwater runoff and stronger winds, associated with the most recent anthropogenic warming, have led to a decrease in chlorophyll concentration and average phytoplankton size (Montes-Hugo et al. 2009; Garcia et al. 2016, 2019). Thompson and Alder (2005) confirmed the low abundance in the WAP area. They found a higher abundance of tintinnids further north, towards the Polar Front, whereas in Antarctic waters, close to Elephant Island, the numbers dropped to near zero, with tintinnids concentration and biomass $<1$ ind. $\mathrm{L}^{-1}$ and $<0.01 \mu \mathrm{g} \mathrm{C} \mathrm{L}{ }^{-1}$, respectively. In a study along the Bransfield Strait (Calbet et al. 2005), ciliates' and dinoflagellates' biomass was low and the distribution was almost uniform within the upper $100 \mathrm{~m}$ of the water column. Ciliate abundances peaked between 40 $\mathrm{m}$ and $80 \mathrm{~m}$ while dinoflagellates had a more homogeneous depth distribution. Also Alder and Boltovskoy (1991) found both tintinnids and dinoflagellates abundances to be $<10$ ind. $\mathrm{L}^{-1}$ in the Bransfield Strait. They did not find foraminifers and radiolarians in the area, and only 4 tintinnid taxa represented over $80 \%$ of all the retrieved specimens. At the stations close to our stations in the Antarctic Sound sampling area, the average abundances varied between 34 ind. $\mathrm{L}^{-1}$ (tintinnids) and 29 ind. $\mathrm{L}^{-1}$ (dinoflagellates) (Alder and Boltovskoy 1991).

In contrast to the northern WAP situation, the reduction of sea ice in the southern WAP area, which was previously permanently ice-covered, caused an increase in phytoplankton biomass (Monte-Hugo et al. 2009). During two cruises along the WAP in January-February 2010 and 2011, Garzio and Steinberg (2013) found an increase in MZP abundance and biomass with latitude from north (around $65^{\circ} \mathrm{S}$ ) to south, with athecate dinoflagellates and aloricate ciliates as the dominant groups (maxima average abundance at $10 \mathrm{~m}$ of 2972 and 4423 ind. $L^{-1}$, respectively).

The low abundance of MZP in our study was also affected due to the sampling season from March to April, when Antarctic plankton rapidly decline, compared to values in December-January, which normally show bloom conditions (Garzio and Steinberg 2013). Both temperature and fluorescence were low, with maximum values in the mixed layer for temperature of $2.05^{\circ} \mathrm{C}$ and the maximum chlorophyll fluorescence value of 6.35 (arb. units), comparable with values outside the productive season (Alder and Boltovskoy 1991; Calbet et al 2005; Thompson and Alder 2005).

Crustacean grazing can have profound effects on microplankton communities over short periods, especially during the productive summer season (Bodungen et al. 1986). Our data on micrometazoans abundance showed different abundances between the three sampling areas. Only in the Deception Island area we found a high micrometazoans versus low tintinnid abundance, suggesting that the low MZP abundance in all three sampling areas are rather caused by hydrological and seasonal dynamics than due to high 
mesozooplankton grazing. In all the studied area, MZP presented higher values at the surface and DMC depths. In accordance with other authors, the significant differences in the community composition between the photic and aphotic layers highlighted the MZP decrease with depth (Wasik and Mikołajczyk 1990; Boltovskoy and Alder 1992; Burkill et al. 1995; Calbet et al. 2005). Other reports in Antarctic waters occasionally describe a higher abundance of MZP in deeper layers (Alder and Boltovskoy 1993; Priddle et al. 1995; Fonda Umani et al. 1998), suggesting that vertical profiles are a result of the combined effect of predator, prey and water stability.

\section{Microzooplankton community composition}

According to PERMANOVA results, significant differences in terms of taxonomic composition and abundance of MZP were found among the three sampling areas. The three areas were significantly different mainly due to the abundance of tintinnids population.

The sampling stations in the Antarctic Sound area were characterized by mixed layer depths close to $100 \mathrm{~m}$, generally with higher salinity and lower temperature, compared to the other two areas. Samples showed high values of agglutinated (Codonellopsis balechi) or weakly agglutinated species (L. naviculaefera). Codonellopsis balechi was detected in all the investigated areas but showed the highest abundance in Antarctic Sound. The high percentage of Codonellopsis balechi can be related to the fact that Antarctic Sound is a neritic area, with high turbulence and advective energy that could be advantageous for tintinnids with a lorica covered mostly with non-biogenic particles. Elephant Island area was characterized by a higher abundance of tintinnids with hyaline lorica such as Codonellopsis glacialis, Cymatocylis convallaria and Cymatocylis drygalskii. Both Codonellopsis and Cymatocylis species are relatively wide-mouthed, presumably feeding on prey with similar dimensions. In both the Antarctic Sound and Elephant Island areas, the low fluorescence values could however indicate the presence of nanophytoplankton instead of big diatoms. High values of tintinnids corresponding to low fluorescence were found at two stations in King George Island during January-February 2011 (Garcia et al. 2016). On the contrary, the Deception Island area was the only one with higher fluorescence, low values of tintinnids and higher abundances of heterotrophic dinoflagellates, aloricate ciliate and micrometazoans.

Two stations offshore (St. 34 and St.106), both located between $61^{\circ} \mathrm{S}$ and $62^{\circ} \mathrm{S}$, presented species not detected in other stations as $N$. pachyderma and Codonellopsis gaussi. Peculiar biological properties can be correlated with the distance from the coast, described as "island mass effect", for other Antarctic areas (Boden 1988). In particular, station 34 presented a different vertical profile showing water masses
(AAIW) with higher temperature and salinity, and higher fluorescence values. The different water masses, combined with food availability, could be the possible reason for the presence of $N$. pachyderma, a planktonic foraminifer that feeds predominantly on diatoms (Spindler et al. 1984) and is common in winter ice, together a high percentage of diatoms (Monti-Birkenmeier et al. 2017). The reason for the presence of Codonellopsis gaussi in the two offshore stations is not clear and is complicated by the fact that this species present different ecophenotypes. Codonellopsis gausii is also part of a group of three species (Codonellopsis gaussi, Cymatocylis calyciformis and Salpingella sp.) with similar abundance trends and the same presence/absence behavior detected by SIMPER that notes higher values in the offshore station.

\section{Tintinnids abundance}

We registered particularly high relative tintinnids abundances. Hydrographic properties were unable to explain the high percentage detected, as tintinnids were generally uniformly distributed. The high percentage of tintinnids in our samples (up to $84 \%$ ) could rather be linked to the sampling season. The annual cycle of tintinnids in Admiralty Bay showed high values until the end of April (Wasik and Mikolajczyk 1994) and, in a study in Terra Nova Bay, tintinnids became more important after the decrease of heterotrophic dinoflagellates (Fonda Umani et al. 2002).

We found higher tintinnids abundance with lower fluorescence values suggesting a selective food supply, probably belonging to pico and/or nanoplankton, characteristic of Antarctic post-bloom conditions (Alder and Boltovskoy 1993). Other studies conducted in an earlier season (Alder and Boltovskoy 1991; Boltovskoy and Alder 1992; Calbet et al. 2005; Garzio and Steinberg 2013; Garcia et al. 2016) recorded aloricate ciliates and dinoflagellates as the majority groups, followed by tintinnids. High aloricate ciliates numbers are recorded in the Antarctic sea ice (Monti-Birkenmeier et al. 2017), and their presence in the water suggests the influence of sea ice and glacial meltwater (Garzio and Steinberg 2013), while tintinnids, not present in sea ice and only in a little number below the ice (Wasik and Mikołajczyk 1990; Monti et al. 2016; Monti-Birkenmeier et al. 2017), are recorded when the population is in a more advanced stage.

The low abundance of aloricate ciliates found in this study could be also associated with the sampling methods. We sampled large volumes of water, reduced them to 250$\mathrm{mL}$ using a $10-\mu \mathrm{m}$ mesh and fixed with buffered formaldehyde. This procedure could result in a cell loss for the more delicate organisms. On the other hand, we only considered aloricate ciliates $>20 \mu \mathrm{m}$ that should have been retained by the used mesh. Furthermore, others authors have used the same fixative and large volume water bottles, combined with 
reverse flow concentration, as the only method that allows sampling for the entire taxonomic assemblage, including delicate forms such as aloricate ciliates and athecate dinoflagellates (Gowing and Garrison 2003).

\section{Tintinnids composition}

The area under study was characterized by the presence of a tintinnids assemblage constituted by eleven species, characteristic of the Southern Ocean except A. laackmanni and the genus Salpingella. Few species dominated the tintinnid associations: Codonellopsis balechi, Codonellopsis glacialis, Cymatocylis convallaria and Cymatocylis drygalskii. These species were recorded in all the Southern Ocean sectors (Boltovskoy et al. 1990; Boltovskoy and Alder 1992; Monti and Fonda Umani, 1995, 2000; Thompson et al. 1999; Petz et al. 1995) and in particular along the WAP area (Wasik and Mikołajczyk 1990; Alder and Boltovskoy 1991; Boltovskoy and Alder 1992; Thompson and Alder 2005; Garcia et al. 2016).

Thompson and Alder (2005) found Codonellopsis gaussi, Cymatocylis calyciformis, Cymatocylis convallaria, Cymatocylis vanhöffeni forma flava and L. naviculaefera forma prolongata in two stations next to Elephant Island. In our samples, Laackmaniella genus has never been abundant, probably because this species seems to prefer high microplanktonic concentrations and low salinities (Boltovskoy et al. 1989; Alder and Boltovskoy 1991). In our samples, L. prolongata was registered only in three stations (St. 17, St. 81 and St. 106). Our findings were in disagreement with Alder and Boltovskoy (1991) that highlighted L. prolongata as abundant under and around ice-covered areas, while we found that $L$. naviculaefera also thrives in open waters. Both the Laackmaniella species were found often in the deeper layers. They are very similar morphologically and could be ecophenotypes of the same genus, rather than independent species (Petz 2005).

Wasik and Mikołajczyk (1990) during a summer cruise in three regions (Admiral Bay, Bransfield Strait and between Elephant Island and the South Orkney Islands) registered Cymatocylis convallaria, Codonellopsis balechi and $L$. naviculaefera as the dominant species. The difference in rare and/or small species could be related to the different methods of sampling, for example net vs Niskin bottles, or to the season.

In the area between $60^{\circ} \mathrm{S}$ and $63^{\circ} \mathrm{S}$, Boltovskoy and Alder (1992) highlighted that tintinnids assemblage was dominated by Cymatocylis convallaria and Codonellopsis gaussi. In the upper $25 \mathrm{~m}$, Codonellopsis gaussi was dominant over Cymatocylis convallaria while in the $50-150 \mathrm{~m}$ interval the latter was more abundant. The same authors, despite the difference in methods (pump vs Niskin bottles), described how $80 \%$ of all tintinnids was due only to three species: Cymatocylis convallaria, Cymatocylis drygalskii and Codonellopsis balechi. In particular, the authors agreeing with this study, highlighted that Codonellopsis balechi was the dominant (almost 80\%) tintinnids in the area close to Antarctic Sound, with Cymatocylis convallaria and Cymatocylis drygalskii contributing to the rest of species (Alder and Boltovskoy, 1991). In our samples, Codonellopsis glacialis was the dominant species, with different percentages in both the Deception and Elephant Island areas, followed by Cymatocylis convallaria, species most abundant in oligotrophic areas (Boltovskoy et al. 1989). Comparison with other studies must take into account that some authors consider Codonellopsis glacialis as a morphotype of Codonellopsis gaussi (Balech 1973; Wasik and Mikołajczyk 1990; Alder and Boltovskoy 1991; Alder 1999; Thompson and Alder 2005) and Cymatocylis convallaria synonymous with Cymatocylis drygalskii (Boltovskoy and Alder 1992; Kim et al. 2013). In this study, we maintained the separation between the species (Petz 2005) but, due to the high polymorphism of Cymatocylis drygalskii (Dolan et al. 2012), we distinguished three different groups according to different lengths whilst acknowledging the constancy of diameter. The basic difference between the three forms was the morphology of the aboral horn of the lorica. The three different sizes were considered as polymorphic species of Cymatocylis drygalskii as the length can depend on the age of the tintinnids, ecological settings in the breeding area (Boltovskoy et al. 1990; Wasik and Mikolajczyk 1994) or food availability (Gold and Morales 1975). For this reason, the length of the bowl and horn are of little use for determination, but they are important for the biomass calculation.

\section{Conclusions}

The MZP community in the WAP area was dominated by tintinnids followed by heterotrophic dinoflagellates. Microzooplankton abundances were comparable to those previously reported for the region. The community composition in the photic and aphotic layers were significantly different and a clear trend in diversity was detected between the three investigated areas. The absence of any correspondence among the different groups, suggested that MZP values can be a result of combined effects in the water column.

All the areas showed low variability in tintinnids and the persistence of a few key species as Codonellopsis balechi, Codonellopsis glacialis, Cymatocylis convallaria and Cymatocylis drygalskii. Comparisons with previous studies carried out earlier in the season, suggest that tintinnids abundance increases toward the late summer to fall, probably in response to an enhanced availability of nanoplankton, characteristic of Antarctic post-bloom conditions. 
Because MZP organisms are directly influenced by environmental conditions, and their distribution and abundance affect higher trophic levels in terms of biodiversity and biogeochemical cycles, the record of Antarctic MZP has become more and more important in predicting future changes in the Southern Ocean ecosystem.

Acknowledgements This work was supported by the Italian National Program for Antarctica (PNRA) with the project PLEASE "Plankton Enigma in the Antarctic Sea Environment" and is a contribution to the German POSER project "Population Shift and Ecosystem Response Krill vs.Salps" funded by the Lower Saxony Ministry for science and culture (MWK). We would like to thank the captain, crew, and chief scientist of RV Polarstern PS112 for their help and support during the cruise. We are grateful to the anonymous reviewer and Wuchang Zhang for their useful comments and suggestions on the manuscript.

Author contributions MM-B was responsible for the study, contributed to the microzooplankton analyses and wrote the paper. TD was involved in the microzooplankton and statistical analyses. THB, ACS and AF were responsible for the hydrographic setting and analyzed data. BM was responsible for the project. All authors contributed to the writing of the paper, read and approved the manuscript.

Funding Open access funding provided by Istituto Nazionale di Oceanografia e di Geofisica Sperimentale within the CRUI-CARE Agreement.

\section{Declarations}

Conflict of interest The authors have no conflicts of interest.

Open Access This article is licensed under a Creative Commons Attribution 4.0 International License, which permits use, sharing, adaptation, distribution and reproduction in any medium or format, as long as you give appropriate credit to the original author(s) and the source, provide a link to the Creative Commons licence, and indicate if changes were made. The images or other third party material in this article are included in the article's Creative Commons licence, unless indicated otherwise in a credit line to the material. If material is not included in the article's Creative Commons licence and your intended use is not permitted by statutory regulation or exceeds the permitted use, you will need to obtain permission directly from the copyright holder. To view a copy of this licence, visit http://creativecommons.org/licenses/by/4.0/.

\section{References}

Alder VA (1999) Tintinnoinea. In: Boltovskoy D (ed) South Atlantic Zooplankton. Backhuys, Leiden, pp 321-384

Alder VA, Boltovskoy D (1991) Microplanktonic distribution pattern west of Antarctic Peninsula, with special emphasis on the tintinnids. Polar Biol 11:103-112

Alder VA, Boltovskoy D (1993) The ecology of larger microzooplankton in the Weddell-Scotia Confluence Area: horizontal and vertical distribution patterns. J Mar Res 51:323-344

Balech E (1973) Segunda contribución al conocimiento del plancton del Mar de Bellinghausen. Contrib Inst Antart Argentino 107:3-63
Balech E (1976) Clave Ilustrada de Dinoflagellados Antarcticos. Publ Inst Antar Argentino 11:1-99

Beans C, Hecq JH, Koubbi P, Vallet C, Wright S, Goffart A (2008) A study of the diatom-dominated microplankton summer assemblages in coastal waters from Terre Adélie to the Mertz Glacier. East Antarctica (139 E-145 E). Polar Biol 31:1101-1117

Beers JR, Stewart GL (1970) Numerical abundance and estimated biomass of microzooplankton. In: Strickland JDH (ed) The ecology of the plankton off La Jolla, California, in the period April through September 1967. University of California Press, Berkeley, pp 67-87

Boden BP (1988) Observations of the island mass effect in the Prince Edward Archipelago. Polar Biol 9:61-68

Bodungen B, Smetacek VS, Tilzer MM, Zeitzschel B (1986) Primary production and sedimentation during spring in the Antarctic Peninsula region. Deep Sea Res Part A 33:17-194

Boltovskoy D, Alder VA (1992) Microzooplankton and tintinnid species-specific assemblage structures: patterns of distribution and year-to-year variations in the Weddell Sea (Antarctica). J Plankton Res 14:1405-1423

Boltovskoy D, Alder VA, Spinelli F (1989) Summer Weddell Sea microplankton assemblage structure, distribution and abundance, with special emphasis on the Tintinnina. Polar Biol 9:447-456

Boltovskoy D, Dinofrio EO, Alder AA (1990) Intraspecific variability in Antarctic tintinnids: the Cymatcylis affinis/convallaria species group. J Plankton Res 12:403-413

Bray JR, Curtis JT (1957) An ordination of upland forest communities of southern Wisconsin. Ecol Monogr 27:325-349

Burkill PH, Edwards ES, Sleigh MA (1995) Microzooplankton and their role in controlling phytoplankton growth in the marginal ice zone of the Bellingshausen Sea. Deep Sea Res 42:1277-1290

Calbet A, Landry MR (2004) Phytoplankton growth, microzooplankton grazing, and carbon cycling in marine system. Limn Ocean 49:51-57

Calbet A, Saiz E (2005) The ciliate-copepod link in marine ecosystem. Aquat Microb Ecol 38:157-167

Calbet A, Alcaraz M, Atienza D, Broglio E, Vaqué D (2005) Zooplankton biomass distribution patterns along the western Antarctic Peninsula (December 2002). J Planton Res 27:1195-1203

Clarke KR, Gorley RN (2015) Getting started with PRIMER v7. PRIMER-E, Plymouth Marine Laboratory, Plymouth

Dietrich G, Kalle K, Krauss W, Siedler G (1975) Allgemeine Meereskunde: Eine Einführung in die Ozeanographie, 3rd edn. Gebrüder Borntrager, Stuttgart

Dolan JR, Pierce RW, Yang EJ, Kim SY (2012) Southern Ocean biogeography of tintinnid ciliates of the marine plankton. J Eukaryot Microbiol 59:511-519

Ducklow H, Clarke A, Dickhut R, Doney SC, Geisz H, Huang K, Martinson DG, Meredith MP, Moeller HV, Montes-Hugo M, Schofield O, Stammerjohn SE, Steinberg D, Fraser W (2012) The marine system of the Western Antarctic Peninsula. In: Rogers AD, Johnston NM, Murphy EJ, Clarke A (eds) Antarctic ecosystem: an extreme environment in a changing world. Blackwell, London, pp 121-159

Edler L (1979) Recommendations for marine biological studies in the Baltic Sea. Phytoplankton and Chlorophyll. Baltic Mar Biol $5: 1-37$

Fonda Umani S, Monti M, Nuccio C (1998) Microzooplankton biomass distribution in Terra Nova Bay, Ross Sea (Antarctica). J Mar Syst 17:289-303

Fonda Umani S, Accornero A, Budillon G, Capello M, Tucci S, Cabrini M, Del Negro P, Monti M, De Vittor C (2002) Particulate matter and plankton dynamics in the Ross Sea Polynya of Terra Nova Bay during the Austral Summer 1997/98. J Mar Syst 36:29-49 
Garcia MD, Hoffmeyer MS, Abbate López MC, Barría de Cao MS, Pettigrosso RE, Almandoz GO, Hernando MP, Schloss IR (2016) Micro- and mesozooplankton responses during two contrasting summers in a coastal Antarctic environment. Polar Biol 39:123-137

Garcia MD, Severini MD, Spetter C, Abbate MC, Tartara MN, Nahuelhual EG, Marcovecchio JE, Schloss IR, Hoffmeyer MS (2019) Effects of glacier melting on the planktonic communities of two Antarctic coastal areas (Potter Cove and Hope Bay) in summer. Reg Stud Mar Sci. https://doi.org/10.1016/j.rsma.2019.100731

Garzio L, Steinberg DL (2013) Microzooplankton community composition along the Western Antarctica Peninsula. Deep-Sea I Res 77:36-49

Gifford DJ, Caron DA (2000) Sampling, preservation, enumeration and biomass of marine protozooplankton. In: Harris R et al (eds) ICES zooplankton methodology manual. Academic Press, London, pp 193-221

Gold K, Morales EA (1975) Seasonal changes in lorica sizes and the species of Tintinnida in the New York Bight. J Protozool 22:520-528

Gowing MM, Garrison DL (2003) Larger microplankton in the Ross Sea: abundance, biomass and flux in the austral summer. In: Ditullio GR, Dunbar RB (eds) Biogeochemestry of the Ross Sea. Wiley, Hoboken, pp 243-260

Kemle-von Mücke S, Hemleben C (1999) Foraminifera. In: Boltovskoy D (ed) South Atlantic Zooplankton. Backhuys, Leiden, pp 43-73

Kim SY, Choi JK, Dolan JR, Shin HC, Lee SH, Yang EJ (2013) Morphological and ribosomal DNA-based characterization of six Antarctic ciliate morphospecies from the Amundsen Sea with phylogenetic analyses. J Eukaryot Microbiol 60:497-513

Kling SA, Boltovskoy D (1999) Radiolaria Phaeodaria. In: Boltovskoy D (ed) South Atlantic Zooplankton. Backhuys, Leiden, pp 213-264

Larik O, Westheide W (2006) Coastal plankton. Photo guide for European seas. Verlag, Munchen

Lessard EJ (1991) The trophic role of heterotrophic dinoflagellates in diverse marine environments. Mar Microb Food Webs 5:49-58

Llanillo PJ, Aiken CM, Cordero RR, Damiani A, Sepúlveda E, Fernández-Gómez B (2019) Oceanographic variability induced by tides, the intraseasonal cycle and warm subsurface water intrusions in Maxwell Bay, King George Island (West-Antarctica). Sci Rep 9:18571. https://doi.org/10.1038/s41598-019-54875-8

McMinn A, Scott FJ (2005) Dinoflagellates. In: Scott FJ, Marchant HJ (eds) Antarctic Marine Protists. Camberra ABRS, Hobart, pp 202-250

Mendes CRB, Tavano VM, Leal MC, de Souza MS, Brotas V, Garcia CAE (2013) Shift in the dominance between diatoms and cryptophytes during three late summers in the Bransfield Strait (Antarctic Peninsula). Polar Biol 36:537-547

Moffat C, Meredith M (2018) Shelf-ocean exchange and hydrography west of the Antarctic Peninsula: a review. Phil Trans R Soc A 376:20170164. https://doi.org/10.1098/rsta.2017.0164

Montes-Hugo M, Doney SC, Ducklow HW, Fraser WR, Martinson D, Stammerjohn SE, Schofield O (2009) Recent change in phytoplankton communities associated with rapid regional climate change along the western Antarctic Peninsula. Science 323:1471-1473

Monti M, Fonda Umani S (1995) Tintinnids in Terra Nova Bay - Ross Sea during two austral summer (1987/88 and 1989/90). Acta Protozool 34:193-201

Monti M, Fonda Umani S (2000) Distribution of the main microzooplankton taxa in the Ross Sea (Antarctica): austral summer 2004. In: Faranda FM, Guglielmo L, Ianora A (eds) Ross Sea Ecology. Springer, Berlin, pp 275-289

Monti M, Zoccarato L, Fonda Umani S (2016) Microzooplankton composition under the sea ice and in the open waters in Terra
Nova Bay (Antarctica). Polar Biol. https://doi.org/10.1007/ s00300-016-2016-9

Monti-Birkenmeier M, Diociaiuti T, Fonda Umani S, Meyer B (2017) Microzooplankton composition in the winter sea ice of the Weddell Sea. Antarct Sci. https://doi.org/10.1017/S0954102016000717

Petz W (2005) Ciliates. In: Scott FJ, Marchant HJ (eds) Antarctic Marine Protists. Camberra ABRS, Hobart, pp 347-448

Petz W, Song W, Wilbert N (1995) Taxonomy and ecology of the ciliate fauna (Protozoa, Ciliophora) in the endopagial and pelagial of the Weddell Sea, Antarctica. Stapfia 40:1-223

Priddle J, Leakey R, Symon C et al (1995) Nutrient cycling by Antarctic marine microbial plankton. Mar Ecol Prog Ser 116:181-198

Putt M, Stoecker DK (1989) An experimentally determined carbon: volume ratio for marine "oligotrichous" ciliates from estuarine and coastal waters. Limnol Oceanogr 34:1097-1107

Sangrà P, García-Muñoz C, García C, Marrero-Díaz Á, Sobrino C, Mouriño Carballido B, Estrada-Allis S (2014) Coupling between upper ocean layer variability and size-fractionated phytoplankton in a non-nutrient-limited environment. Mar Ecol Prog Ser 499:35-46

Schmidt K, Atkison A, Petzke K, Voss M, Pond DW (2006) Protozoans as a food source for Antarctic krill, Euphasia superba: complementary insights from stomach content, fatty acids, and stable isotopes. Limonol Oceanogr 51:2409-2427

Sherr E, Sherr B (2007) Heterotrophic dinoflagellates: a significant component of microzooplankton biomass and major grazers of diatoms in the sea. Mar Ecol Prog Ser 352:187-197

Siedler G, Griffies SM, Gould J, Church JA (2013) Ocean circulation and climate: a 21st century perspective. Academic Press, London

Spindler M, Hemleben C, Salomons JB, Smit LP (1984) Feeding behavior of some planktonic foraminifers in laboratory cultures. J Foraminiferal Res 14:237-249

Talley L, Pickard G, Emery W, Swift J (2011) Descriptive physical oceanography, 6th edn. Elsevier, Amsterdam

Thompson GA, Alder VA (2005) Patterns in tintinnid species composition and abundance in relation to hydrological conditions of the southwestern Atlantic during austral spring. Aquat Microb Ecol 40:85-101

Thompson GA, Alder VA, Boltovskoy D, Brandini F (1999) Abundance and biogeography of tintinnids (Ciliophora) and associated microzooplankton in the southwestern Atlantic Ocean. J Plankton Res 21:1265-1298

Turner J, Bindschadler R, Convey P, di Prisco G, Fahrbach E, Gutt J, Hodgson D, Mayewski P, Summerhayes C (2009) Antarctic climate change and the environment. Scientific Committee on Antarctic Research, Cambridge

Utermöhl H (1958) Zur Vervollkommung der quantitativen Phytoplankton-Methodik. Mitt Int Ver Theor Angew Limn 9:1-38

Verity PG, Langdon C (1984) Relationship between lorica volume, carbon, nitrogen, and ATP content of tintinnids in Narragansett Bay. J Plankton Res 6:859-868

Wasik A, Mikołajczyk E (1990) Tintinnids near Pack-Ice between South Shetland and South Orkney Islands (26 Dec. 1988-18 Jan. 1989). Acta Protozool 29:229-244

Wasik A, Mikołajczyk E (1994) Annual cycle of tintinnids in Admiral Bay with an emphasis on seasonal variability in Cymatocylis affinis/ convallaria lorica morphology. J Plankton Res 16:1-8

Whitehouse M, Meredith M, Rothery P, Atkinson A, Ward P, Korb R (2008) Rapid warming of the ocean around south Georgia, Southern Ocean during the 20th century: forcings, characteristics and implications for lower trophic levels. Deep-Sea Res I 55:1218-1228

Publisher's Note Springer Nature remains neutral with regard to jurisdictional claims in published maps and institutional affiliations. 